\title{
Association between Accounting Numbers and Value of Food and Beverages Firms in Nigeria
}

\author{
Nyor Terzungwe ${ }^{1} \&$ Nasiru Rabiu ${ }^{1}$ \\ ${ }^{1}$ Department of Accounting, Faculty of Arts and Social Sciences, Nigerian Defence Academy, Kaduna, Nigeria \\ Correspondence: Nyor Terzungwe, Department of Accounting, Faculty of Arts and Social Sciences, Nigerian \\ Defence Academy, Kaduna, Nigeria. Tel: 234-805-442-3022. E-mail: loterz@yahoo.com
}

Received: September 25, 2015

doi:10.5539/ijef.v7n12p245

\author{
Accepted: October 26, $2015 \quad$ Online Published: November 25, 2015
}

URL: http://dx.doi.org/10.5539/ijef.v7n12p245

\begin{abstract}
The degree of statistical relationship between the contents of financial statements and market price of equity is what is termed Value relevance of accounting information. It explains stock market measures using financial information variables and it is a very useful guide to investors in pricing of shares. This study examines the extent of association between accounting information variables of earnings, dividend and book value of equity and market value of listed Food and Beverages firms in Nigeria. Data were collected from the published annual reports of the sampled firms and their market values obtained from the official daily list of the Nigerian Stock Exchange (NSE) over a period of 10 years (2001-2010). Using multivariate regression as technique for data analysis, the study established that accounting information of Food \& Beverages companies in Nigeria is value relevant. Accordingly, the study recommends the use of financial statements figures of Food and Beverages firms for investment decision.
\end{abstract}

Keywords: value relevance, accounting information, financial statements, share price, book value

\section{Introduction}

Accounting information plays a significant role within the concept of generation, summarization, preparation and communicating wealth of companies to shareholders and other stakeholders. It is compressed in financial statements such as balance sheet (now statement of financial position), income statement, cash flow statement and value added statement (which no longer exist in IFRS financial statements). It also contains other information given as foot notes (qualitative and quantitative) either to supplement or explain the data in the accounts.

The objectives of accounting information are to provide information about financial position, financial performance, and changes in financial position of an enterprise and summarily, that information must be understandable, relevant, reliable and comparable (IASB, 2007). The function of financial reporting is to provide information that is useful to those who make economic decision about enterprises' investments or loans. Hence, relevance of accounting information is a primary quality of financial reporting.

Accounting information must be related to company's value and be able to give a predictive strength on the value of a firm for it to appropriately guide a decision. If there is no association between accounting information and a company's value then accounting information cannot be termed relevant, and therefore unable to fulfill one of its primary objectives. The ability of accounting numbers to capture certain attributes of stock prices is what is termed in the literature as value relevance of accounting information. It is the measurement of association between accounting figures and market price of companies (Barth, Beaver, \& Landsman, 2001).

Since the value of a firm is strongly related to its performance, the use of information contents of financial statement in establishing correlation between security prices/returns and some accounting variables has gained considerable attention in the finance and accounting literature. Ball and Brown (1968) are reputed to be the first to carry out a study to investigate the usefulness of financial accounting report in determining the market price of equities. Accounting information must achieve relevance in presenting accounting figures for effective decision making and also enhance the capital markets in supplying the information.

Many studies have been carried out in Nigeria to examine the relationship between the contents of financial report of listed companies and the market value of their equities but used little scope in the period covered 
(Abubakar, 2005; Thompson, 2010; Maradum 2010; Oyerinde, 2011; Ibiamke and Abanyam (n.d); Uthman \& Abdul-Baki, 2014; Oshodin \& Mgbame, 2014; Adebimpe \& Ekwere, 2015). Studies with short scope do not generate robust analysis to guarantee enduring conclusions. Hence, this study has expanded the scope to ten years from 2001 to 2010 and employs a more recent period and industry specific to verify the claims of past studies. The scope stops at 2010 in order not mix accounting information prepared under local GAAP and IFRS in view of the adoption of IFRS in the Country. Studies by Adaramola and Oyerinde (2014) and, Omokhudu and Ibadin (2015) spanned to twenty years but they cut across different industries which do not use common classification, treatment and measurement of items. Accounting information is more comparable within the same industry than across different industries. We could not sight single industry value relevance studies on the Food and Beverages industry in Nigeria. Hence this study is domiciled in the F\&B industry in Nigeria.

Another reason for the choice of the sector is because it has been reported for a case of creative accounting, the situation which led to one of the companies being placed under a technical suspension (Onaf, 2008). Hence, this study aims at determining whether accounting information in the sector is still value relevant for economic decisions. Specifically, the study measures the association between earnings per share, dividend per share, book value per share and market value of Quoted Food and Beverages firms to test for their value relevance.

The choice of Nigeria for the study area is because it has become an investment destination as one of the emerging economies in Africa. Apart from the Banking industry that is thriving, the Food and Beverages industry is fast growing in Nigeria. With the recent Government policy of diversifying the economy from oil which accounts for more than ninety percent of her budget to agriculture, the Food and Beverages industry, whose dominant inputs are agricultural products is about to experience a boost. This study will assist potential investors who might want to rely on value relevance variables for investment decisions.

This paper is divided into five sections. Section two reviews related literature on value relevance of accounting information of Nigerian firms, while section three is on the methodology adopted for the study. Section four presents data analysis and discussion of the results and section five draws conclusions and offers recommendation

\section{Literature Review}

Relevance is an accounting concept that tries to create rationality that the information produced by an entity should influence meaningfully the decision-making ability of its users (Bonham et al., 2009). The concept of relevance revolves round the contents of the accounting information and its timeliness, both of which can impact significantly on decision making. In particular, information that is provided to users faster is considered to have an increased level of relevance.

Accounting as a language of business traditionally starts with the identification, summarizing, and recording of financial data, to preparation of financial reports and terminates with the analysis of the prepared reports by different stakeholders for different purposes (AAA cited in Barde, 2009). Like every piece of information, accounting information is generated for specific purposes. The objectives of preparing financial reports include planning for the organizations immediate and long term needs, provision of historical financial information, providing basis for controlling the organization and making informed decision (Deegan, 2007).

Value relevant studies in Nigeria ca; $2 \mathrm{n}$ be classified into two broad categories: those based on financial statement prepared under IFRS and those based on financial statement prepared under the local GAAP. Ibiamke and Abanyam (n.d) studied the impact of IFRS on value relevance of accounting information in Nigeria using "same year" design where financial statements reported under Statement of Accounting Standards (SAS) for the penultimate year of IFRS adoption is restated under IFRS in the year of adoption. The study had a sample of 35 firms across different industries listed on the Nigerian Stock Exchange as at 2011. They found that adoption of IFRS has significantly increased value relevance of financial statements in Nigeria.

Uthman and Abdul-Baki (2014) investigated the perception of analysts concerning value relevance of accounting information in Nigeria in the IFRS regime using questionnaire. They concluded that IFRS adoption has enhanced value relevance of accounting information in Nigeria. Adebimpe and Ekwere (2015) studied IFRS adoption and value relevant of financial statements in Nigerian listed banks, comparing the pre-adoption period of 2010 and 2011 with post-adoption period of 2012 and 2013. The result indicated that earnings per share are increasingly value relevant during post-IFRS period and book value of equity per share is increasingly less relevant during post-IFRS period.

Value relevant studies based on financial statement prepared under the local GAAP in Nigeria can be further classified into cross industry and single industry studies. Adaramola and Oyerinde (2014) did a trend analysis of 
value relevance of financial accounting information of quoted companies in Nigeria taking 66 firms from financial and non financial firma from 1990 to 2009. Their study revealed that accounting information of quoted firms in Nigeria is value relevant. However, the value relevance is weak in the period of political instability caused by military dictatorship (1992-1998) and global economic crises (2008-2009). We have observed that studies that cut across different industries which do not use common classification, treatment and measurement of items are less comparable. Accounting information is more comparable within the same industry than across different industries.

Omokhudu and Ibadin (2015) studied value relevance of accounting in Nigeria fro 1994-2013 using a sample of 47 firms in all industries excluding finance quoted on the NSE. They used ordinary least square estimation with fixed and random effect variants in the regression. Their study found that earnings, cash flow and dividend were significantly associated with firm value but book value of equity shares was not significantly related. This study, apart from cutting across many industries and becoming less comparable also cuts across the period of local GAAP and IFRS. Financial statements prepared under different accounting standards lack a common basis for comparison.

Under single industry value relevant studies, Thompson (2010) measured the association between accounting information and market share prices of listed cement manufacturing firms in Nigeria during the stock market crisis. The study used Ohlson model (1995) to empirically measure the correlation between book value per share and market share price of cement industry from 2007 to 2012. The study found that despite the stock market crisis the accounting information of cement manufacturing firms is value relevant. The study therefore concluded that there was a significant relationship between accounting information and the market share price of cement manufacturing firms in Nigeria. However, it can be observed that Adaramola and Oyerinde (2014) found that value relevance was weak during the period of global economic Crises (2008-2009) in Nigeria.

Maradun (2010) examined the extent to which market values are associated with firms characteristics (book value, cash flows, dividend and earnings). The study covered the period from 2001 to 2006 and used Ohlson's price model to establish the relationship. The study concluded that there was a significant positive impact on the shares of manufacturing firms in Nigeria. Oyerinde (2011) investigated the value relevance of accounting data in the Nigerian stock market. She used linear regression on a sample size that comprised of 30 firms with highest earnings yield for a period of 4 years from 2001 to 2004. In her conclusion, the study showed that accounting information of Nigerian listed firms' was value relevant.

Abubakar (2011) used the Ohlson's model to establish the degree to which the accounting information of Telecommunication, Media and Technology (TMT) firms in Nigeria firms' influence shares price valuation using book value per share, adjusted earnings per share and changes in earnings per share over a four year period (2005-2008). The findings from the study revealed that accounting information of listed TMT firms in Nigeria has no significant value relevance. The study attributable the low value relevance of accounting information of TMT firms to the exclusion of value of intangibles in the accounting information. However, the scope of the study is too short to generate robust data and arrive at an enduring conclusion.

Oshodin and Mgbam (2014) did a comparative study of value relevance of financial information in Nigerian banking and petroleum sectors taking a sample of 10 companies from 2007 to 2011. Using book value of equity, earnings per share and leverage as independent variables, the regression results under ordinary least square showed that financial information in the oil and gas industry is more value relevant than that of the banking sector.

\section{Methodology}

The population of this study consists of 14 food and beverages firms quoted on the floor of the Nigerian Stock exchange. However, firms with non-active stocks due to technical suspension or delisting and firms without trading information during the period of the study from 2001 to 2010 were excluded from the study. This saw five firms namely Beverages West Africa Plc, Ferdinand Oil Mills Plc, Foremost Dairies Plc, Tate Industries Plc and UTC Nigeria Plc excluded from the study. The remaining nine firms that formed the sample for the study are 7-Up Bottling Company Plc, Cadbury Nigeria Plc, Flour Mills Nigeria Plc, National Salt Co. Nigeria Plc and Nestle Foods Nigeria Plc. Others are Nigerian Bottling Company Plc, Northern Nigeria Flour Mills Plc, P S Mandarides \& Co. Plc and Union Dicon Salt Plc.

\subsection{Variables Definition and Measurement}

This study consists of dependent and independent variables. The dependent variable is the market price per share (MPS). A share price is the price of a single share of a number of saleable stocks of a company, derivative or 
other financial asset (Ehrhardtand Brigham, 2010). The stock price is the highest amount someone is willing to pay for the stock, or the lowest amount that it can be bought for. The market price per share is also called the intrinsic value of a share of stock or the actual value based on the actual variables taken from the company's accounting information. For the purpose of this study, the current trading price based on investors' buying and selling behavior is considered.

The independent variables are Book Value per share (BVPS), Dividend per Share (DPS) and Earnings per Share (EPS). A company's book value is its total assets minus intangible assets and liabilities. It is sometimes referred to as stockholder's equity, owner's equity, shareholder's equity, or simply, equity (Maradun, 2010). In the United Kingdom, the term net asset value may refer to the book value of a company (Rapport, 1986). Book value per share is obtained by dividing Owners' equity divide over the Number of stock shares outstanding.

Dividend fund appropriated out of the profits of a corporation and distributed among its stockholders either in a form of cash dividend or share repurchase (VanHorne and Wachowiccz, 2009). Dividend per share (DPS) is the total dividends paid out over an entire year (including interim dividends but not including special dividends) divided by the number of outstanding ordinary shares issued. Earnings per share (EPS) are the amount of income that belongs to each share of common stock and any preferred dividends actually declared in the current year are subtracted. It is calculated as Net Income over Average Number of Shares Outstanding during Period. Net Income equals to Revenue minus cost of sales, operating expenses, and taxes, over a given period of time (Stewart, 1989).

The data used for this study are from annual reports of the individual firm and the fact book of the Nigerian Stock Exchange. The secondary data were analyzed using Pearson Correlation and multivariate regression techniques using the Ordinary Least Squares (OLS) regression. Multicolinearity is tested using correlation.

\section{Data Analysis ad Discussion of Results}

This section presents and discusses the results obtained from the data that were collected and analysed. It begins with the analysis of descriptive statistics. The researcher employed the use of STATA (version 11.3) to carry out the analysis.

\subsection{Descriptive Statistics}

The descriptive statistics of the data collected for the study is presented and discussed in this section. The summary of the descriptive statistics is presented in Table 1 as follows:

Table 1. Descriptive statistics

\begin{tabular}{ccccccc}
\hline Variables & Mean & SD & Min & Max & Skewness & kurtosis \\
\hline MPS & 41.2074 & 62.4039 & 0.63 & 368.55 & 3.0280 & 12.9861 \\
BVPS & 8.4782 & 7.2458 & -4.44 & 26.95 & 0.4574 & 2.4697 \\
EPS & 2.0327 & 3.5978 & -5.07 & 17.66 & 1.7970 & 7.8262 \\
DPS & 0.8124 & 1.1939 & 0.00 & 8.35 & 3.5428 & 20.5415 \\
\hline
\end{tabular}

Source: STATA OUTPUT (version 11.3).

The descriptive statistics from Table 1 shows that the market price per share (MPS) of quoted food and beverages firms during the period of the study is N41.21k on average, with standard deviation of 62.4039 .

The standard deviation indicates that the MPS of the sample firms deviate from both sides of the mean by N62.40, suggesting that the data is widely dispersed from the mean value. The minimum and maximum values of MPS are N0.63 and N368.55 respectively. The coefficient of skewness on the other hand is 3.0280 implying that the data is positively skewed. Most of the data are on the right side of the normal curve. The value of kurtosis 12.9861 also support that the data from MPS did not follow the normal distribution, which is also evidenced by the wide range (the difference between the minimum and maximum value).

Also, from the Table 1 indicates that the average book value per share (BVPS) of quoted food and beverages firms during the period of the study is N8.4782, with standard deviation of 7.2458. The standard deviation implies that the BVPS of the sample firms deviate from both sides of the mean by N7.25, suggesting that the data is widely dispersed from the mean value. The minimum and maximum values of BVPS are $-\mathrm{N} 4.44$ and N26.95 respectively. The coefficient of skewness of 0.4574 implying that the data is positively skewed, most of the data are on the right side of the normal curve. The kurtosis value of 2.4697 suggests that the data from BVPS did not follow the normal distribution, which is also evidenced by the wide range (difference between the 
minimum and maximum value). The table also shows that the earnings per share (EPS) of quoted food and beverages firms during the period of the study is N2.0327, with standard deviation of 3.5978. The standard deviation implies that the EPS of the sample firms deviate from both sides of the mean by N3.59, suggesting that the data is widely dispersed from the mean value. The minimum and maximum values of EPS are -N5.07 and N17.66 respectively. The coefficient of skewness of 1.7970 implying that the data is positively skewed, most of the data are on the right side of the normal curve. The kurtosis value of 7.8262 suggests that the data from EPS did not follow the normal distribution, which is also evidenced by the wide range (difference between the minimum and maximum value).

Lastly, Table 1 shows that the dividend per share (DPS) of quoted food and beverages firms during the period of the study is N0.8124 on average, with standard deviation of 1.1939. The standard deviation indicates that the DPS of the sample firms deviate from both sides of the mean by N1.19, suggesting that the data is widely dispersed from the mean value. The minimum and maximum values of DPS are N0.00 and N8.35 respectively. The coefficient of skewness on the other hand is 3.5428 implying that the data is positively skewed; most of the data are on the right side of the normal curve. The value of kurtosis 20.5415 also support that the data from DPS did not follow the normal distribution, which is also evidenced by the wide range (the difference between the minimum and maximum value).

Therefore, the descriptive statistics of the variables of the study shows the nature and extent of dispersion of the data, which to a large extent suggested that the data did not follow the normal curve. Therefore, the test of normality is conducted and the results of data normality test of the variables are presented in Table 2.

Table 2. Results for normal data test

\begin{tabular}{lccccc}
\hline Variables & W & V & Z & P-Value & N \\
\hline MPS & 0.9650 & 2.645 & 2.145 & 0.0159 & 90 \\
BVPS & 0.9678 & 2.437 & 1.965 & 0.0247 & 90 \\
EPS & 0.8436 & 11.828 & 5.449 & 0.0000 & 90 \\
DPS & 0.6845 & 23.863 & 6.997 & 0.0000 & 90 \\
\hline
\end{tabular}

Source: STATA OUTPUT (Version 11.3).

The study applied Shapiro-Wilk (W) test for normal data. Under this technique, null hypothesis principle is used to check a variable that came from a normally distributed population. The null hypothesis of the test is that the data is not normally distributed. Table 2 indicates that data from the variables of the models of the study are not normally distributed because the P-valueis significant at $1 \%$ and $5 \%$ level of significance $(0.0000,0.0000$, 0.0159 and 0.0247 ). Thus, the null hypothesis (that, the data is not normally distributed) is accepted for all the variables. This suggests that the model of the study may require a more generalized regression technique.

Table 3. Correlation matrix (P-Value in parentheses)

\begin{tabular}{|c|c|c|c|c|}
\hline Variables & MPS & BVPS & EPS & DPS \\
\hline MPS & 1.0000 & & & \\
\hline BVPS & $\begin{array}{c}0.6543 \\
(0.0000)\end{array}$ & 1.0000 & & \\
\hline EPS & $\begin{array}{c}0.7273 \\
(0.0000)\end{array}$ & $\begin{array}{c}0.4050 \\
(0.0000)\end{array}$ & 1.0000 & \\
\hline DPS & $\begin{array}{c}0.6293 \\
(0.0000)\end{array}$ & $\begin{array}{c}0.2879 \\
(0.0059)\end{array}$ & $\begin{array}{c}0.6023 \\
(0.0000)\end{array}$ & 1.0000 \\
\hline
\end{tabular}

Source: STATA OUTPUT (Version 11.3).

The correlation matrix in Table 3 indicates a significant positive association between market price per share (MPS) and book value per share (from the correlation coefficient of 0.6543), earnings per share (from the correlation coefficient of 0.7273) and dividend per share (from the correlation coefficient of 0.6293) of the sample firms at $1 \%$ level of significance (with the p-value of 0.0000 ). This result implies that book values, earnings and dividends of quoted food and beverages firms during the period of the study were value relevant and capable of influencing investors' decisions. The result also indicates the absence of multicolinearity among 
the independent variables. The regression results of the study are presented in Table 4 below:

Table 4. Model summary of robust random effect regression

\begin{tabular}{lcc}
\hline Variables & Statistics & P-Value \\
\hline R Square: Within & 0.3561 & \\
R Square: Between & 0.8267 & 0.0000 \\
R Square: Overall & 0.7131 & 0.2868 \\
Wald Chi2 & 72.95 & 0.0000 \\
Hausman Specification Test: Chi2 & 3.77 & 0.0017 \\
Random Effect Test: Chi2 & 71.26 & 9.82 \\
Hettest: Chi2
\end{tabular}

Source: STATA OUTPUT (Version 11.3).

The assumptions of Ordinary Least Squares Regression with regards to panel data require the model to be fit and unbiased for a valid interpretations and conclusions. As such this study subjected the model to other regression models (Fixed and Random Effects) in addition to pooled OLS and the robustness tests conducted. For instance, the results in Table 4 shows a presence of Heteroskedasticity in the panel as indicated by the Breuch Pagan/Cook-Weisberg test for heteroskedasticity, Chi2 of 9.82 with p-value of 0.0017 . This proved that the assumption of constant variance of the error term (homocedasticity) is not been met, and as a result OLS estimators will not be best linear unbiased estimators (BLUE). This is corrected using robust regression (heteroskedasticity corrected standard errors), after the results of random effect test, Breusch and Pagan Lagrangian Multiplier Test for Random Effects, which indicated that there is statistical significant variance among the units in the panel (Chi2 of 71.26 with p-value of 0.0000), implying that OLS regression is not an appropriate technique for the study. This is also supported by the Hausman specification test, which also indicates that random effect regression is the most appropriate for the study.

The results from Table 4 indicate that the accounting information variables (book value, earnings and dividend per share) explained 71.31\% of the total variations in the market price of Quoted Food and Beverages Firms in Nigeria during the period of the study, from the overall coefficient of determinations. The table also shows that the model is fit at $99 \%$, confidence level. This significant explanatory power of the accounting information with regards to market price implies higher value relevance. However, the individual impact of accounting information variable is analyzed in Table 5 below.

Table 5. Regression coefficients

\begin{tabular}{lccc}
\hline Variables & Coefficients & Z-Value & P-Value \\
\hline BVPS & 0.0596 & 5.70 & 0.000 \\
EPS & 0.1438 & 5.21 & 0.000 \\
DPS & 0.1469 & 3.76 & 0.000 \\
CONSTANT & 1.9840 & 7.60 & 0.000 \\
\hline
\end{tabular}

Source: STATA OUTPUT (Version 11.3).

With the coefficient of 0.0596 with Z-value of 5.70, which is statistically significant at $1 \%$ level of significance (p-value of 0.000), book value per share has significant impact on market price of quoted Food and Beverages firms in Nigeria. This implies that a N1 increase in book value, market price increases by $5.96 \mathrm{~K}$. Based on this evidence, the study posits that book value per share has significant impact on market price of quoted Food and Beverages and firms in Nigeria.

Dividend per share (DPS) of Quoted Food and Beverages Firms in Nigeria have significant positive impact on the market price during the period, from the coefficient of 0.1469 with $\mathrm{Z}$-value of 3.76, which is statistically significant at $1 \%$ level of significance (p-value of 0.000). This implies that a N1 increase in dividend, market price increases by $14.69 \mathrm{~K}$ and the results is statistically significant at $1 \%$ level of significance. Based on this evidence, the study posits that dividends of Quoted Food and Beverages Firms in Nigeria have significant effect on the market price and therefore value relevant. This study is inconsonance with the conclusion of Oyerinde (2011) that have found positive impact on the overall value relevance of financial statements using a sample of 
30 firms with the highest yield across Nigerian stock market from 2001 to 2004. This study also agreed with the findings of Thompson (2010) who both conducted their study using cement manufacturing firms in Nigeria. The study was conducted during the stock market crisis and was able to establish that there was a significant relationship between accounting information and the market prices.

Table 5 indicates that earnings per share (EPS) of Quoted Food and Beverages Firms in Nigeria have significant positive impact on the market price during the period, from the coefficient of 0.1438 with Z-value of 5.21 which is statistically significant at $1 \%$ level of significance (p-value of 0.000 ). This implies that a $\mathrm{N} 1$ increase in earnings, market price increases by $14.38 \mathrm{~K}$ and the results is statistically significant at $99 \%$ confidence level. With this evidence, the study concludes that earnings of Quoted Food and Beverages Firms in Nigeria have significant effect on the market price and therefore value relevant. This study is consistent with Babalola (2010) who investigated the value relevance of accounting information of listed companie;s across different sectors of Nigerian Stock market from 1999 to 2009 with a sample of 40 firms. He found that earnings are more value relevant in driving the firm's value than book values. The study also agreed with the position of Maradun (2010) who conducted a study using manufacturing firms in Nigeria. His findings on the characteristics of firms showed a positive impact and therefore value relevant.

\section{Conclusion and Recommendation}

From the data analysis carried out, the study was able to establish that the book value per shares, dividend per share (DPS) and earnings per share (EPS) of Quoted Food and Beverages Firms in Nigeria have significant positive impact on the market price during the period. Hence, the study concludes that earnings, book value and dividends of the Quoted Food and Beverages Firms in Nigeria are value relevant. Accordingly, the study recommends that existing and potential investors in Nigeria should consider food and beverages firms while making investments decision.

\section{References}

Abubakar, S. (2011). Value relevance of accounting information of listed new economy firms in Nigeria: An empirical investigation using Ohlson model. Paper presented at the International Conference on Accounting and Finance in Africa organised by the Department of Accounting and Finance, University of Ghana in collaboration with the Department of Accounting and Finance, University of Brinmingham, UK.

Adaramola, A. O., \& Oyerinde, A. A. (2014). Value Relevance of Financial Accounting Information of Quoted Companies in Nigeria: A Trend Analysis Research. Journal of Finance and Accounting, 5(8).

Adebimpe, O. U., \& Ekwere, R. E (2015). IFRS Adoption and Value Relevance of Financial Statements of Nigerian Listed Banks. International Journal of Finance and Accounting, 4(1), 1-7.

Babalola, Y. A. (2012). Significance of accounting information on corporate values of firms in Nigeria. Research Journal in Organizational Psychology \& Educational Studies, 1(2), 105-113.

Ball, R., \& Brown, P. (1968). An Empirical Evaluating of Accounting Income. Journal of Accounting Research, 6(1), 159-781. http://dx.doi.org/10.2307/2490232

Barde, I. M. (2009). An evaluation of accounting information disclosure in the Nigerian oil marketing industry. (Ph.D's Thesis). Bayero University, Kano.

Barth, M. E., Beaver, W. H., \& Landsman, W. R. (2001). The Relevance of the Value Relevance Literature for Financial Accounting Standard Setting: Another View. Journal of Accounting and Economics, 31(1-3), 77-104. http://dx.doi.org/10.1016/S0165-4101(01)00019-2

Bonham, M., Richard, C., Curtis, M., Davies, M., Dekker, P., Denton, T., \& Williams, T. (2009). International GAAP 2009 under International Financial Reporting Standards. Chichester: John Wiley \& Sons .

Deegan, C. (2007). Financial accounting theory. North Ryde, NSW, Australia McGraw-Hill Irwin.

Ibiamke, N. A., \& Abanyam, I. E. (n.d). The Impact of International Financial Reporting Standards (IFRS) on Value Relevance of Accounting in Nigeria. Retrieved 14 October, 2015 from https://www.google.com/search?q=IBIAMKE+NICHOLAS+ADZOR\&ie=utf-8\&oe=utf-8

Maradun, S. M. (2010). The Impact of Firms' Characteristics on Market Value of Quoted Manufacturing Firms in Nigeria. M.sc thesis submitted, A.B.U Zaria.

Ohlson, J. A. (1995). Earnings, Book Values and Dividends in Equity Valuation. Contemporary Accounting Research Journal, 11, 661-870. http://dx.doi.org/10.1111/j.1911-3846.1995.tb00461.x

Omokhudu O. O., \& Ibadin P. O. (2015). The Value Relevance of Accounting Information: Evidence from 
Nigeria. Accounting and Finance Research, 4(3). http://dx.doi.org/10.5430/afr.v4n3p20

Onaf, A. (2008). Cadbury Plc, Akintola William and Union Registrar Hammered by SEC. Retrieved from http:/nairaland.com/126888/Cadbury-plc-akintola-william-union

Oshodin, E., \& Mgbame, C. O. (2014). The Comparative Study of Value Relevance of Financial Information in the Nigeria Banking and Petroleum Sectors. Journal of Business Studies Quarterly, 6(1).

Oyerinde, D. T. (2011). Value Relevance of Accounting Information in Nigerian Stock Market. Retrieved from http://www.slideshare.net/fullscreen/zorro29/value-relevance-of-accounting-information

Thompson, F. D. (2010). The Problem of Many Hands in Restoring Responsibility: Ethics in Government, Business and Health Care (pp. 33-49). Cambridge University Press.

Uthman, A. B., \& Abdul-Baki, Z. (2014). The value-relevance of accounting information in Nigeria: Analysts' perception in the IFRS regime. Journal of Accounting and Management, 4(1).

\section{Copyrights}

Copyright for this article is retained by the author(s), with first publication rights granted to the journal.

This is an open-access article distributed under the terms and conditions of the Creative Commons Attribution license (http://creativecommons.org/licenses/by/3.0/). 